\begin{tabular}{|c|l|}
\hline Title & The Pelagic Feeding Ecology of Thick-billed Murres in the North Pacific, March - June \\
\hline Author(s) & OGI, Haruo \\
\hline Citation & 北海道大學水産學部研究彙報, 31(1), 50-72 \\
\hline Issue Date & 1980-03 \\
\hline Doc URL & http://hdl.handle.net/2115/23705 \\
\hline Type & bulletin (article) \\
\hline File Information & 31(1)_P50-72.pdf \\
\hline
\end{tabular}

Instructions for use 
Bull. Fac. Fish. Hokkaido Univ.

31(1). 50-72. 1980.

\title{
The Pelagic Feeding Ecology of Thick-billed Murres in the North Pacific, March - June*
}

\author{
Haruo OGI**
}

\begin{abstract}
Several permanent current systems exist in the North Pacific, each of which has unique bio-oceanographic features. Within the pelagic portion of each subarctic system, Thick-billed Murres (Uria lomvia) are present and within each current system, their main prey organisms are affected by a complex of biological and environmental factors.

The diet of Thick-billed Murres was analyzed, using birds drowned in salmon gill nets during the period March through June. Overall, the importance of food items, by average weight percentage, were as follows: squid $(72.6 \%)$, fish $(16.7 \%)$, ouphausiids $(10.6 \%)$ and amphipods $(0.05 \%)$. Thus, squid by far proved to be the most important prey, including such species as Gonatopsis borealis (mantle length: $6.5-10.5 \mathrm{~cm})$, Berryteuthis magister $(4-9.5 \mathrm{~cm})$ and $B$. anonychus $(8-10$ om). Squid larvae were also at times important, as were very large individuals. The dependence on squid is an essential character for seabird survival in the pelagic environment of the North Pacific.
\end{abstract}

\section{Introduction}

Based on my unpublished observations, Thick-billed Murres (Uria lomvia) occur throughout the pelagic portion of the subarctic North Pacific from late autumn to early in the next summer. The southern limit of their distribution coincides approximately with the Subarctic Boundary, and the northern limit by the southern edge of pack ice. Common Murres (Uria aalge), on the other hand, were not observed in pelagic areas farther than about $500 \mathrm{~km}$ from the land. The Thick-billed Murre is thus more pelagic than the latter species.

In the North Pacific Ocean several permanent current systems exist, each of which has peculiar bio-oceanographic characteristics. Thick-billed Murres feed on a variety of prey in the epipelagic layer of each current system. One can assume that their stomach contents reflect the real time bio-oceanographic habitat of the environments they frequent. Based on this assumption, I attempted to clarify the food and feeding habits of Thick-billed Murres in the North Pacific Ocean. $I$ also present here, for comparative purposes, some information on diets of other birds.

* Contribution No. 109 from the Research Institute of North Pacific Fisheries, Faculty of Fisheries, Hokkaido University

** Research Institute of North Pacific Fisheries, Faculty of Fisheries, Hokkaido University (北海道大学水産学部 北洋本産研究施設 漁策部門) 


\section{OGI: Pelagic feeding ecology of Thick-billed Murres}

\section{Materials and Methods}

This study is based on seabirds, and particularly Thick-billed Murres, incidentally drowned by gill nets set for salmon. The birds were obtained at 58 of 69 stations in the northwestern North Pacific Ocean where gill net fishing was conducted by the following vessels: in 1972, $R V$ Oyashio Maru (Oy) from March 18 to April 21 and $R V$ Habomai Maru No. $21(\mathrm{Hb})$ from April 18 to May 5; and in 1973, TS Hokusei Maru (Ho) from June 12 to 19, RV Habomai Maru No. 21 from April 21 to 29 and from June 7 to 11, RV Oyashio Maru from April 18 to May 16, TS Iwaki Maru (Ik) from April 19 to May 13, RV Hokushin Maru (Hn) on April 19, RV Iwate Maru (It) from April 22 to May 18 and TS Riasu Maru No. 2 (Ri) from April 25 to June 25 (Fig. 1). A sampling station code was devised using the ship's name (first two letters), sampling year (first digit), month (second digit) and day (last two digits). The following pairs of sampling stations signify the same place: Hb3607 and Hb3608, Hb3610 and Hb3611, Oy2421 and Oy3421, and Oy2420 and Oy3420. The sampling stations between $44^{\circ} \mathrm{N}$ and $47^{\circ} \mathrm{N}$ and $160^{\circ}$ $\mathrm{E}$ and $170^{\circ} \mathrm{E}$ lie very close to each other due to intensive salmon fishing there from May to June in 1972 and 1973.

These sampling stations cover much of the northwestern North Pacific Ocean between $40^{\circ} \mathrm{N}$ and $52^{\circ} \mathrm{N}$ (just south of the Aleutian Islands) and between $150^{\circ} \mathrm{E}$ (near the Kuril Islands) and $160^{\circ} \mathrm{W}$ (Fig. 1). Oceanographically, this is the subarctic Pacific Ocean, and contains such water masses as the Western Subarctic Domain (including the Western Subarctic Gyre), the Alaskan Stream Domain, the Central Subarctic Domain (including the Subarctic Current), and the Transitional Domain representing the West Wind Drift, the Subarctic Boundary and its neighboring subtropical waters ${ }^{1)}$. Sampling was geographically concentrated in the

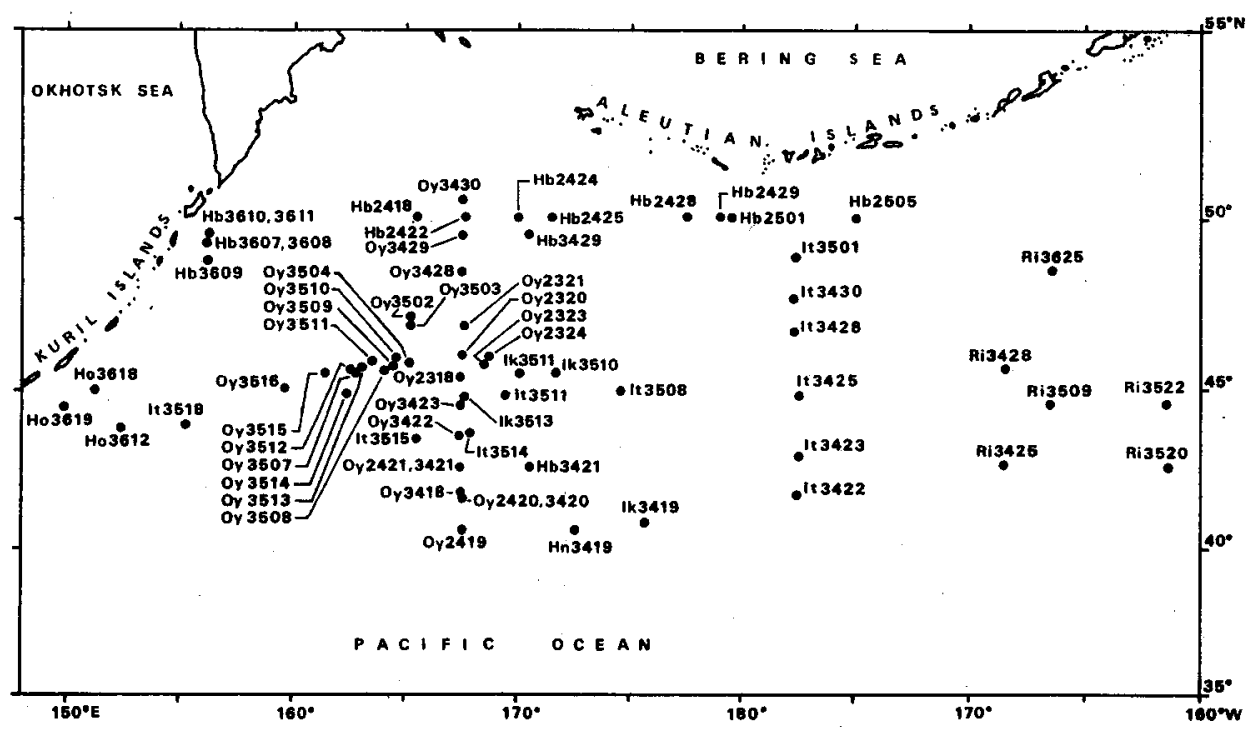

Fig. 1. Locations where murres were sampled for stomach content analysis in 1972 and 1973. 
Bull. Fac. Fish. Hokkaido Univ. 31(1). 1980.

northwestern part of the North Pacific Ocean. Since sampling periods extended from late March to early May in 1972 and late April to mid June in 1973, oceanographic conditions in geographically identical areas could be expected to differ in the two years. Along the

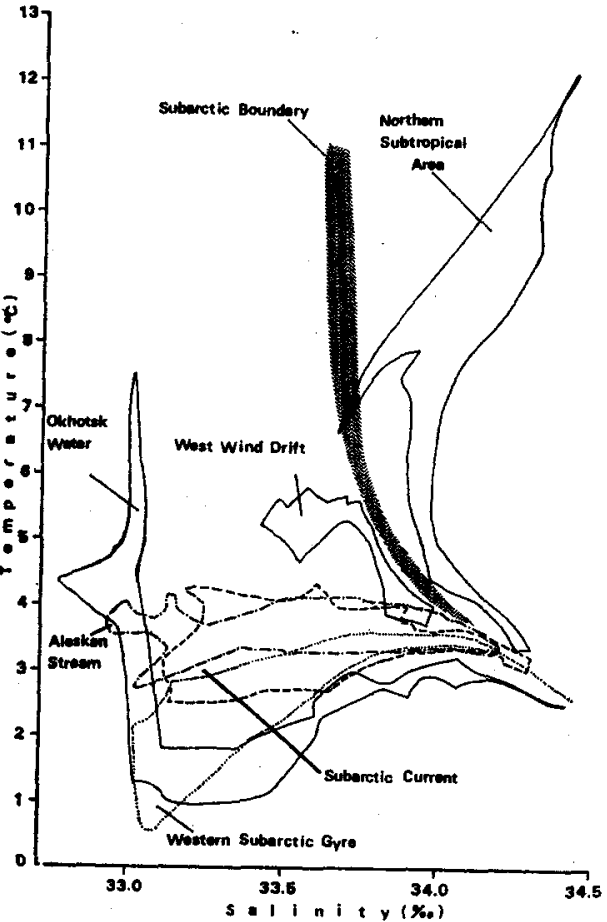

Fig. 2. T-S diagram of water systems in the northern North Pacific Ocean. line of $167^{\circ} 30^{\prime} \mathrm{E}$, where both temperature and salinity data were available in 1972 and 1973 , north-south vertical profiles delineated the water masses. The temperature and salinity structure on this line in both years was almost the same. However, the position of the Subarctic Boundary changed slightly, occurring at about $43^{\circ} 00^{\prime} \mathrm{N}$ in 1972 and at $42^{\circ} 00^{\prime} \mathrm{N}$ in 1973. To provide a better understanding of basic oceanographic features in the region, the horizontal distribution of temperature at various depths were averaged for March to June (Fig. 2). Data were combined for both years.

By referring to Dodimead et al.1), Dodimead $^{2)}$, Favorite ${ }^{3}$, Hirano ${ }^{4)-7),}$ Koto and Fujii ${ }^{8}$, Ohtani ${ }^{9)-11)}$, Uda $^{12)-}$ 13), Kikuchi and Tsujita ${ }^{14}$, and by making T-S diagrams when such data were available, the stations could be grouped into the following six areas: Okhotsk Water, Western Subarctic Gyre, Subaretic Current, Alaskan Stream, West Wind Drift and northern subtropical area (Figs. 2 and 3). No oceanographic observations other than BTs were made at Sts.Hb3607-3711 in the East Kamchatka Current. This current, which arises from anti-clockwise circulation around the Bering Sea, is of low salinity due to ice-melt water and land drainage from the Kamchatka coast ${ }^{12)}$. This current is very weak in comparison with the warmer Alaskan Stream running westward south of the Aleutian Islands (Ohtani pers. comm.). The sampling stations were grouped into the 7 areas on the possibility that the stomach contents of the seabirds reflected the bio-oceanogaphic habitat in each.

Stomach contents in each Thick-billed Murre were identified and grouped into the following types: fish, euphausiids, amphipods, squid, Thecosomata, insects, unidentifiable digested matter $(\mathrm{dm})$ and other materials. The last group was further classified into fish otoliths, squid beaks, pebbles, land grass and seeds, seaweed, plastic particles, and unidentifiable matter. All items were weighed to the nearest $0.001 \mathrm{~g}$. Fresh items were identified to species and their individual numbers were recorded. As described in Ogi and Tsujita ${ }^{15}$, seabirds taken in the 
Oar: Pelagic feeding ecology of Thick-billed Murres

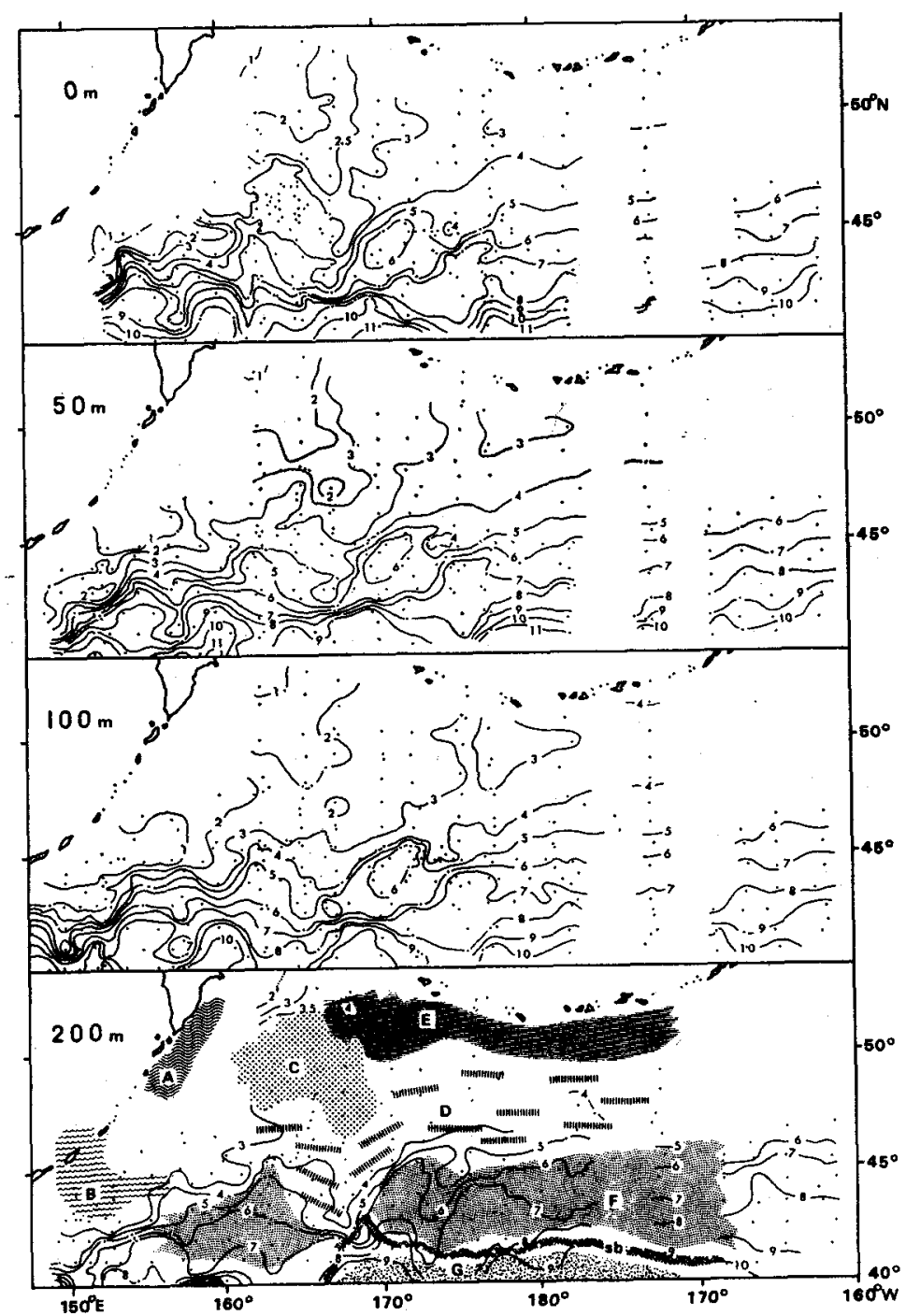

Fig. 3. Horizontal distribution of temperature $\left({ }^{\circ} \mathrm{C}\right)$ at $0,50,100$, and $200 \mathrm{~m}$ depths during the period from late April to early June. Data in 1972 and 1973 were combined. A: East Kamchatka Current, B: Okhotsk Water, C: Western Subarctic Gyre, D: Subarctic Current, E: Alaskan Stream, F: West Wind Drift, sb: Subarctic Boundary, G: Northern Subtropical area.

salmon gill net operation were not always suitable for a full quantitative analysis of food. In almost all cases the proventriculus and ventriculus were empty. This was probably due to the fact that their feeding did not necessarily coincide with the period when nets were set, from the evening to early morning. Diet could change depending on the time of feeding. Seabirds might also regurgitate when struggling in the net meshes ${ }^{16}$ ). 
Bull. Fac. Fish. Hokkaido Univ. 31(1). 1980.

For each station the following were determined: the weight percentage of each prey species in the total stomach contents $(W \%$ ), the mean weight of each prey species in the total number of samples $(\overline{\mathrm{W}} \mathrm{g})$, the number of stomachs in which each prey occurred $(\mathrm{N})$ and its percentage (frequency of occurrence: $\% \mathrm{~F}$-value ${ }^{17}$ ) in the total number of stomachs examined $(\mathrm{P})$, the range in weight of each prey species (Rw), and the mean weight of each species in the total number of stomachs in which that item occurred $(\overline{\mathrm{w}})$. The stations in each oceangoraphic area were then combined to calculate the total weight percentage of food by types, total mean weight of each food type, total number of stomachs in which each type occurred and its percentage in the total number of stomachs. Other materials such as fish otoliths, squid beaks etc., which were almost always found in the gizzard of the seabirds, were negligible. However these materials provided indirect information.

\section{Results}

Analysis of Stomach Contents

Common Murre

Common Murres were obtained from two stations, one individual from $\mathrm{Hb} 3607$ and three from $\mathrm{Hb} 361 \mathrm{l}$ in the East Kamchatka Current. All stomach contents consisted of unidentifiable digested matter of negligible weight $(\mathrm{Hb} 3607: \mathrm{n}=1$, $0.34 \mathrm{~g} ; \mathrm{Hb3611:} \mathrm{n}=3$, range $0.03-0.24 \mathrm{~g}, \overline{\mathrm{x}}=0.17 \mathrm{~g}$ ).

Thick-billed Murre

\section{i. Diet composition by percent weight within areas.}

In the East Kamchatka Current, sampling stations were similar in time and locality. The feeding habits of murres at each of the five stations were also similar. The main prey were euphausiids, which at three stations (Hb3607, Hb 3608 and $\mathrm{Hb} 3610$ ) contributed over $84 \%$ of the wet weight. This area among all others showed the highest weight percentage of euphausiids. Fish were the least important prey and contributed less than $2 \%$ of the weight (Fig. 4).

In the Okhotsk Water area, the number of samples was so small that a detailed description is not possible. At St.Ho3618, 86\% of the prey weight was fish and was assumed to be the main prey in this area (Fig. 4).

In the Western Subarctic Gyre, fish were eaten at four of six stations. At Oy3428, fish contributed $78 \%$ of the weight but at the other three stations they were of minor importance, i.e., $17 \%$ at $\mathrm{Hb} 2418,5 \%$ at $\mathrm{Hb2422}$ and $2 \%$ at Oy 2323 . Euphausiids were eaten at $\mathrm{Hb} 2418$ and $\mathrm{Hb2422}$, contributing $17 \%$ and $19 \%$ of the weight, respectively. Amphipods were found at $\mathrm{Hb2422}$ but were negligible in amount. Squid occurred at four out of six stations and contributed substantially to the diet, i.e., $57 \%$ at $\mathrm{Hb} 2418,88 \%$ at $\mathrm{Oy} 3430,70 \%$ at $\mathrm{Hb} 2422$ and $95 \%$ at $\mathrm{Oy}$ 2321 (Fig. 4).

In the Subarctic Current, sampling stations were distributed widely, and sampling time was restricted to March 1972 and from late April to late June 1973. Fish were eaten at six stations. At two of these (Oy2324 and Oy3422) fish 
Oar: Pelagic feeding ecology of Thick-billed Murres

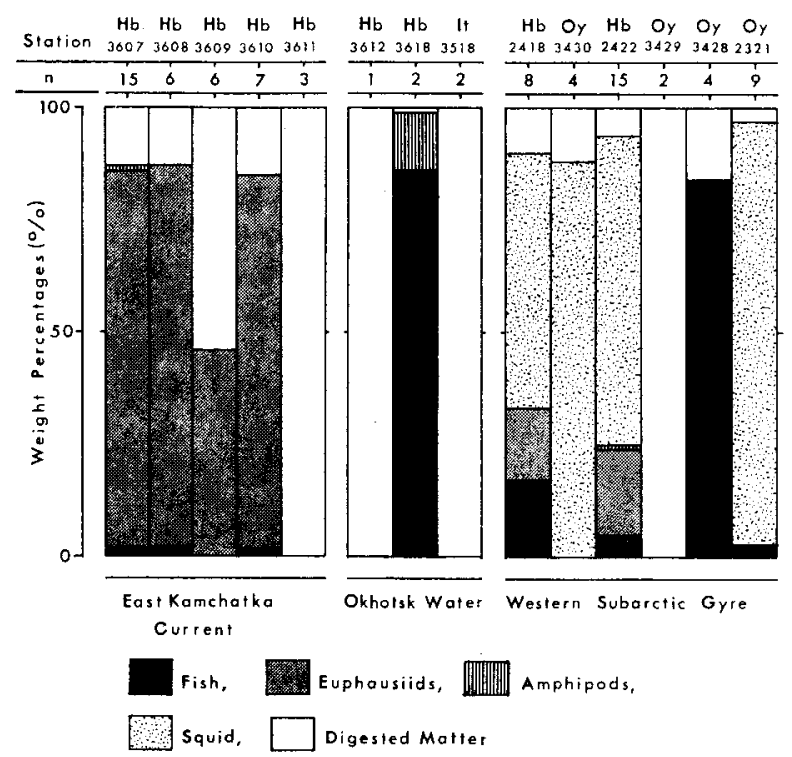

Fig. 4. Food composition by weight percentage for Thick-billed Murres in the East Kamchatka Current, Okhotsk Water and Western Subarctic Gyre.

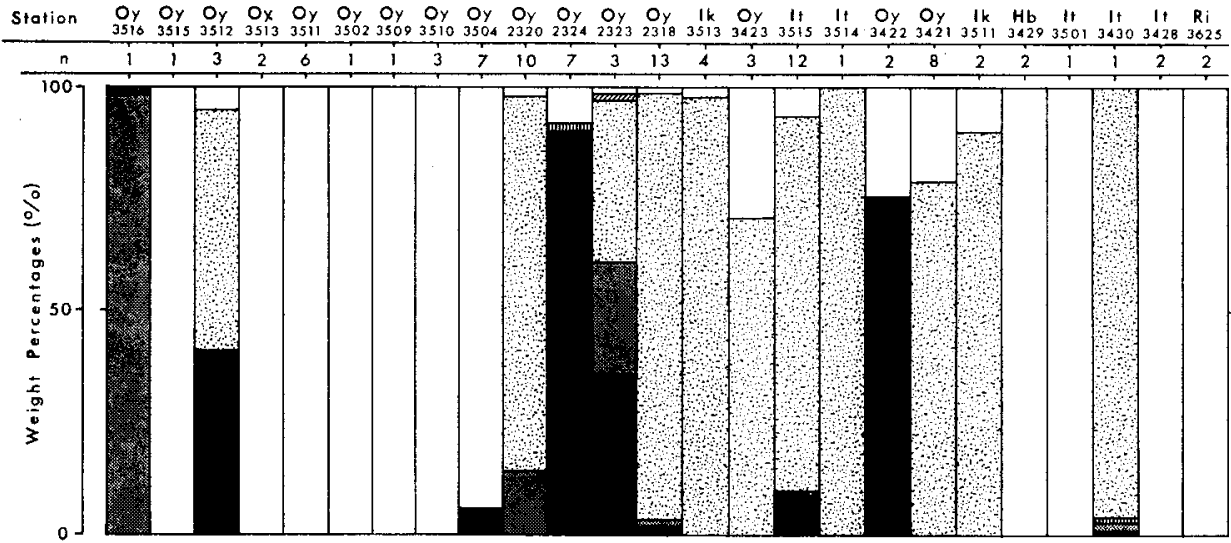

Fig. 5. Food composition by weight percentage for Thick-billed Murres in the Subarctic Current. See also legend to Fig. 4.

amounted to over $75 \%$ of the weight; at all remaining stations, excluding It3430, fish contributed less than $40 \%$. Fish were found in the stomachs mostly in the western part of the Subarctic Current where there is mixing with Okhotsk Water ${ }^{5}$. For the whole Subarctic Current, though, the total weight percentage of fish was no more than $9 \%$ (Fig. 7) ranking this area fourth in the prevalence of fish as prey. Euphausiids were eaten at 5 stations, and were found exclusively at Oy3516, the most westward station in this area. Though the weight percentage of euphausiids 
Bull. Fac. Fish. Hokkaido Univ. 31(1). 1980.

at Oy 2323 was $25 \%$, at the other three stations (Oy2320, Oy2318 and It3430) it was less than $14 \%$. This made euphausiids third in importance as a food item (Fig. 7). Squid were eaten at 11 stations, and exclusively at 5 stations. Squid beaks, however, were found in gizzards at all stations other than Oy3515. This indicates, at the least, that squid were eaten in the recent past by the birds. How long squid beaks stay in the gizzard is not known, but possibly they do so for many days. In the Subarctic Current the total weight percentage of squid was $78 \%$, ranking it second in squid among all areas. Neustonic organisms, such as amphipods, Thecosomata and insects, were of minor importance and were probably taken accidentally. It is interesting that in this area, stomachs containing only unidentifiable digested matter were observed at ten stations. The relatively high frequency of this phenomenon suggests that murre feeding times were quite different than other stations. Thus, from area to area, perhaps depending on the prey, the feeding time of murres may differ considerably (Fig. 5).

In the Alaskan Stream, squid were eaten at all sampling stations and were the dominant prey. At four stations, excluding $\mathrm{Hb2429}$, they contributed 74 to $95 \%$ of the weight. The total weight percentage was $75 \%$, ranking this area third among all others (Fig. 7). Fish and euphausiids were of minor importance, except that at $\mathrm{St} . \mathrm{Hb} 2429$, fish comprised $76 \%$ of the weight. The above results suggest that fish and euphausiids are important prey only when murres encounter them in dense patches (Fig. 6).

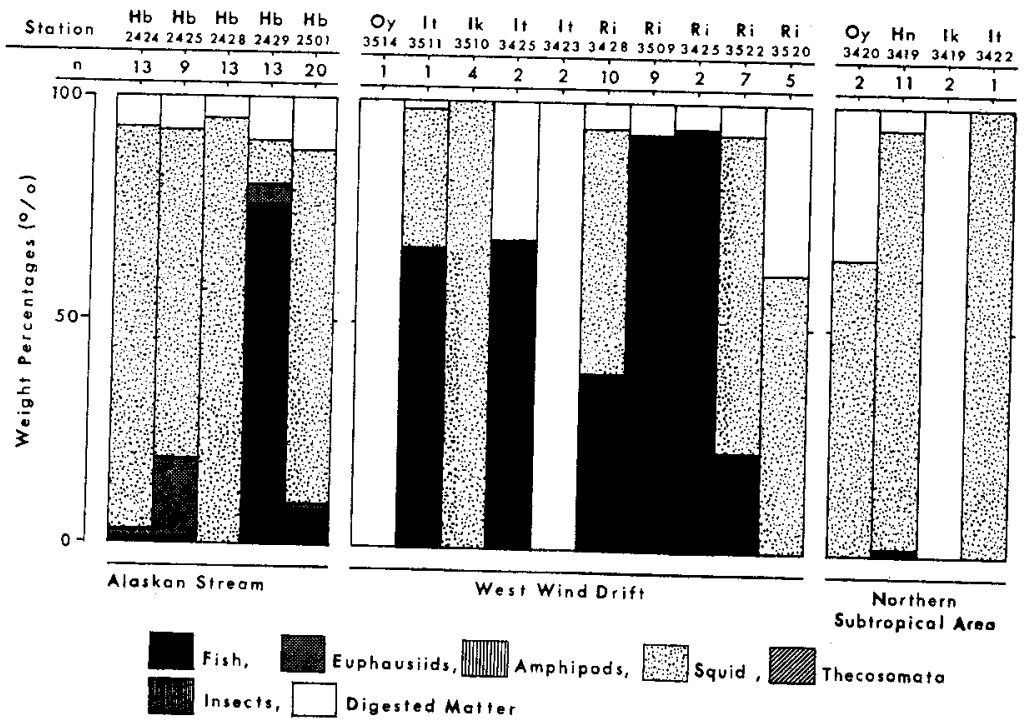

Fig. 6. Food composition by weight percentage for Thick-billed Murres in the Alaskan Stream, West Wind Drift and northern subtropical area.

In the West Wind Drift, only fish and squid were eaten. The total weight percentage of these organisms was $38 \%$ and $56 \%$, respectively, ranking this area second in fish and fifth in squid (Fig. 7). Fish were eaten at six stations, ranging 
from $22 \%$ to $95 \%$ of the weight, and squid at five stations, ranging from $55 \%$ to $100 \%$ of the weight (Fig. 6).

In the northern subtropical area, squid were eaten at three of four stations where they contributed from $66 \%$ to $100 \%$ of the weight. The total weight of squid for all stations was $85 \%$, the highest value among all areas (Fig. 7). Fish were observed only at Hn3419 and contributed only $1 \%$ of the weight (Fig. $6)$.

The above results were analyzed using Whittaker's method ${ }^{18)}$ to determine similarities of percentages (Table 1). Diets in the East Kamchatka Current and Okhotsk Water areas showed quite low percentage similarities when compared with diets in other areas. These results are related to the fact that in those two areas, squid did not occur in the murre stomachs. In the remaining areas, squid contributed over $56 \%$ of the total weight. These two areas were thus quite different feeding biotopes. Furthermore, the East Kamchatka Current differed from the Okhotsk Water area in the dominant food item, euphausiids being the main prey in the former and fish in the latter. The highest percentage similarities were observed in comparisons

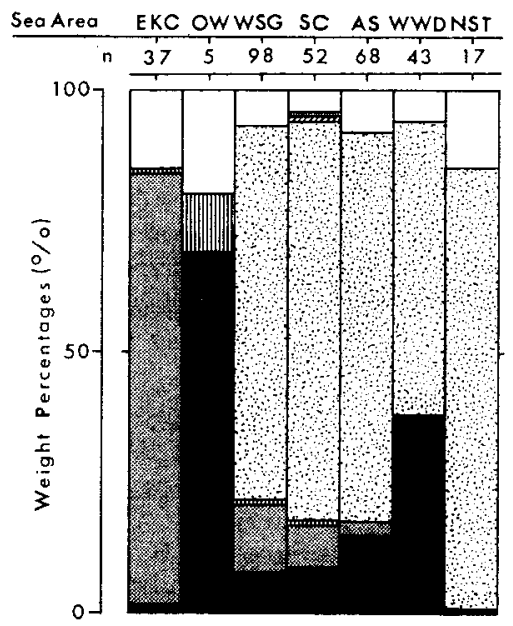

Fig. 7. Food composition by weight percentage for Thick-billed Murres in each sea area of the northern North Pacific Ocean. See also legends to Table 1 and Fig. 6. among the Western Subarctic Gyre, Subarctic Current and Alaskan Stream areas, all of which were adjacent to one another. This was due largely to the fact that fish and euphausiids occurred together with squid being by far the dominant prey. Murre diet in the West Wind Drift showed moderately high percentage similarities in comparisons with the Western Subarctic Gyre, Subarctic Current and Alaskan Stream. The percentage similarity between

Table 1. Percentage similarities of the food composition of Thick-billed Murre among areas in the northern North Pacific Ocean.

\begin{tabular}{c|c|c|c|c|c|c|c}
\hline & EKC & OW & WSG & SC & AS & WWD & NST \\
\hline EKC & - & 17.5 & 21.0 & 15.1 & 12.1 & 7.6 & 15.6 \\
OW & & - & 14.9 & 14.6 & 23.0 & 44.2 & 15.6 \\
WSG & & & - & 94.0 & 89.9 & 69.9 & 79.9 \\
SC & & & & - & 91.7 & 70.4 & 83.8 \\
AS & & & & & - & 76.9 & 83.1 \\
WWD & & & & & & - & 62.5 \\
NST & & & & & & & - \\
\hline
\end{tabular}

EKC: East Kamchatka Current, OW: Okhotsk Water, WSG: Western Subaretic Gyre, SC: Subaretic Current, AS: Alaskan Stream, WWD: West Wind Drift, NST: Northern Subtropical Area 
the West Wind Drift and its neighboring northern subtropical area was much lower. Though the northern subtropical area was completely different oceanographically from the subarctic regions, murre diet there showed high percentage similarities in comparisons with the Western Subarctic Gyre, Subarctic Current and Alaskan Stream. This might indicate that the northern subtropical region could be a favorable feeding and overwintering area for the Thick-billed Murre.

\section{ii. Diet analysis per individual Thick-billed Murre}

The range in weight and the mean weight of stomach contents per murre in each area are shown in Table 2, where areas are arranged in order of decreasing mean values.

Table 2. Stomach content weight (wet weight in grams) per individual Thick-billed Murre in each current system. Numbers in parentheses denote the number of stomachs containing only unidentifiable digested matter $(\mathrm{dm})$. These stomachs were considered to be empty.

\begin{tabular}{l|r|r|r|r}
\hline \multicolumn{1}{c|}{ Area } & N (n) & Range (g) & Mean (g) & Rank \\
\hline West Wind Drift & $43(19)$ & $0.20-90.15$ & 10.03 & 1 \\
Subarctic Current & $98(55)$ & $0.03-112.72$ & 8.58 & 2 \\
Alaskan Stream & $68(37)$ & $0.17-51.89$ & 7.10 & 3 \\
Western Subarctic Gyre & $52(33)$ & $0.02-38.04$ & 6.47 & 4 \\
East Kamchatka Current & $37(25)$ & $0.11-33.96$ & 3.32 & 5 \\
Northern Subtropics & $17(13)$ & $0.00-12.79$ & 1.57 & 6 \\
Okhotsk Water & $5(3)$ & $0.31-4.91$ & 1.48 & 7 \\
\hline
\end{tabular}

The highest mean weight was approximately seven times as much as the lowest. Decreasing mean weights coincided with a decreasing prevalence of empty stomachs $\left(r_{s}=0.750, \mathrm{P}<0.01\right)$ and a decreasing maximum stomach content weight in each area $\left(r_{s}=0.965, \mathrm{P}<0.01\right)$. Maximum stomach content weights for single individuals occurred at St.Ik3513 in the Subarctic Current and at St.Ik3510 in the West Wind Drift. Stomach content weight at the former accounted for $10.1 \%$ and at the latter for $7.3 \%$ of the body weight. Maximum stomach content weights in other areas were much smaller.

The time of day between net setting and net hauling was almost the same at every sampling station. Therefore the stomach contents are probably affected by the following: first, the availability for Thick-billed Murres of food organisms in the surface layer; second, the effective feeding time as related to the target species, oceanographic conditions and season even in the same area; and third, the different digestion rates for different sizes and types of prey.

iii. Occurrence frequency, weight range and the mean weight of prey compared to the total number of stomachs in which each species occurred.

Percentages of stomachs containing each prey type in each area ranged from $5.9 \%$ to $40 \%$ for fish, $7.4 \%$ to $30 \%$ for euphausiids, 1.9 to $20 \%$ for amphipods, 24 to $35 \%$ for squid, and $1 \%$ for Thecosomata and insects (Table 3). Unidentifiable digested matter ranged from 58 to $80 \%$. The dominant food item comprised $30 \%$ (euphausiids) of the total in the East Kamchatka Current and $40 \%$ (fish) in the

$$
-58-
$$


Table 3. The number of stomachs $(N)$ in which each food item occurred and its percentage $(P)$ in the total stomachs examined, the range $(R w)$ in weight of each prey species, and the mean weight $(\bar{w})$ of each food item compared to the total number of stomachs in whih that prey occurred.

\begin{tabular}{|c|c|c|c|c|c|c|c|c|c|}
\hline Area & $\mathbf{N}$ & & Fish & Euphausiids & Amphipods & Squid & Theco* & Insects & $\mathrm{dm} * *$ \\
\hline East Kamchatka Current & 37 & $\begin{array}{l}N(P) \\
R w \\
\bar{w}\end{array}$ & $\begin{array}{l}4(10.8) \\
0.20-0.88 \\
0.48\end{array}$ & $\begin{array}{c}11(29.7) \\
0.05-33.96 \\
9.21\end{array}$ & $\begin{array}{c}1(2.7) \\
0.05 \\
0.05\end{array}$ & $\overline{-}$ & $\overline{-}$ & $\overline{-}$ & $\begin{array}{l}27(73.0) \\
0.11-2.64 \\
\quad 0.72\end{array}$ \\
\hline Okhotsk water & 5 & $\begin{array}{l}\mathrm{N}(\mathrm{P}) \\
\mathrm{Rw} \\
\overline{\mathrm{w}}\end{array}$ & $\begin{array}{l}2(40) \\
1.04-4.08 \\
2.56\end{array}$ & - & $\begin{array}{l}1(20) \\
0.83 \\
0.83\end{array}$ & - & - & - & $\begin{array}{l}4(80) \\
0.01-0.70 \\
0.37\end{array}$ \\
\hline Western Subarctic Gyre & 52 & $\begin{array}{l}N(P) \\
R w \\
\bar{w}\end{array}$ & $\begin{array}{l}6(11.5) \\
0.07-7.57 \\
4.54\end{array}$ & $\begin{array}{c}5(9.6) \\
0.16^{-29.95} \\
8.50\end{array}$ & $\begin{array}{c}1(1.9) \\
0.04 \\
0.04\end{array}$ & $\begin{array}{c}14(26.9) \\
0.38-38.04 \\
17.39\end{array}$ & $\overline{-}$ & - & $\begin{array}{l}36(69.2) \\
0.02-2.08 \\
0.64\end{array}$ \\
\hline Subarctic Current & 98 & $\begin{array}{l}\mathbf{N}(\mathbf{P}) \\
\mathbf{R} w \\
\overline{\mathbf{w}}\end{array}$ & $\begin{array}{c}15(15.3) \\
0.01-18.98 \\
5.07\end{array}$ & $\begin{array}{c}8(8.2) \\
0.01-22.91 \\
8.25\end{array}$ & $\begin{array}{l}2(2.0) \\
0.01-0.06 \\
0.04\end{array}$ & $\begin{array}{c}29(29.6) \\
0.44-112.72 \\
22.47\end{array}$ & $\begin{array}{r}1(1.0) \\
0.005 \\
0.005\end{array}$ & $\begin{array}{c}1(1.0) \\
0.03 \\
0.03\end{array}$ & $\begin{array}{l}70(71.4) \\
0.03-2.40 \\
0.67\end{array}$ \\
\hline Alaskan Stream & 68 & $\begin{array}{l}\mathbf{N}(\mathbf{P}) \\
\mathbf{R w} \\
\overline{\mathbf{w}}\end{array}$ & $\begin{array}{c}10(14.7) \\
0.25-45.34 \\
7.29\end{array}$ & $\begin{array}{l}5(7.4) \\
0.02-7.95 \\
2.47\end{array}$ & $\begin{array}{l}- \\
-\end{array}$ & $\begin{array}{c}23(33.8) \\
0.60-51.16 \\
15.62\end{array}$ & $\underline{-}$ & $\begin{array}{l}- \\
- \\
-\end{array}$ & $\begin{array}{l}50(73.5) \\
0.13-1.90 \\
0.76\end{array}$ \\
\hline West Wind Drift & 43 & $\begin{array}{l}N(P) \\
R w \\
\bar{w}\end{array}$ & $\begin{array}{l}16(37.2) \\
0.93-32.91 \\
10.29\end{array}$ & $\begin{array}{l}- \\
-\end{array}$ & - & $\begin{array}{c}15(34.9) \\
0.22-37.21 \\
16.05\end{array}$ & $\begin{array}{l}- \\
-\end{array}$ & - & $\begin{array}{c}25(58.1) \\
0.18-2.69 \\
1.03\end{array}$ \\
\hline Northern Subtropics & 17 & $\begin{array}{l}\mathbf{N}(\mathrm{P}) \\
\mathbf{R w} \\
\overline{\mathrm{w}}\end{array}$ & $\begin{array}{c}1(5.9) \\
0.18 \\
0.18\end{array}$ & $\frac{-}{-}$ & 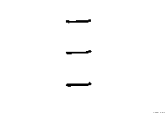 & $\begin{array}{c}4(23.5) \\
1.57-12.61 \\
5.21\end{array}$ & $\overline{-}$ & $\overline{-}$ & $\begin{array}{c}13(76.5) \\
0.03-1.21 \\
0.30\end{array}$ \\
\hline
\end{tabular}

* Thecosomata.

** Unidentifiable digested matter. 
Bull. Fac. Fish. Hokkaido Univ. 31(1). 1980.

Okhotsk Water area. In the remaining areas, squid were the dominant prey, comprising $27 \%$ of the total in the Western Subarctic Gyre, $30 \%$ in the Subarctic Current, 34\% in the Alaskan Stream, 35\% in the West Wind Drift and $24 \%$ in the northern subtropics.

In the West Wind Drift, squid registered the highest values for the total weight percentage $(\mathrm{W} \%)$, total mean weight $(\overline{\mathrm{W}})$ and mean weight $(\overline{\mathrm{w}})$ but the numerical importance of squid (P) was smaller than for fish. Fish were eaten by murres in all areas but their weight range was mostly lower than squid. It is in general thought that pelagic fish are smaller in size and have softer tissues than neritic species. Conceivably birds could digest prey at different rates thus affecting the results. Fish and squid seemed to be prefered by Tick-billed Murres in the pelagic environment. The lack of squid in their diet in the East Kamchatka Current and Okhotsk Water areas was probably due to fish scarcity which in turn, may have been related oceanographic conditions.

Prey of the Thick-billed Murre and other alcid species.

i. Fish.

East Kamchatka Current:

At three sampling stations (Hb3607, $\mathrm{Hb3608}$ and $\mathrm{Hb3610}$ ), all the fish were half-digested; all were juvenile Atka mackerel (Pleurogrammus monopterigius; total length: $20-35 \mathrm{~mm}$ ). Stomach contents of birds that fed on this species were characteristically greenish. In this area I also sampled and analysed the stomach contents of 93 Tufted Puffins (Lunda cirrhata). Their main prey were larval or juvenile fish and squid, euphausiids, pteropods, and a few amphipods and jelly fish. Fish, euphausiids and squid were quantitatively the dominant prey. One Tufted Puffin at St.Hb3610, fed on five juvenile sculpin (Cottidae). Since these birds usually eat small neustonic organisms, all of which digest rapidly, sorting the stomach contents was impossible in almost all cases. Compared to the puffin, the Thick-billed Murres seemed to eat larger organisms or organisms that swarmed densely in the surface layer. As described above, they ate much fish.

Okhotsk Water area:

At one station (Ho3618) out of three, larval fish were eaten by two Thick-billed Murres. Digestion had progressed and some fish had become fragmented, making identification difficult, but all were Atka mackerel. In comparison, one Horned Puffin (Fratercula corniculata) and One Tufted Puffin, at St.Ho3612, fed on three Atka mackerel (total length: 50-60 mm) and juvenile lantern fish (Myctophidae), respectively.

Western Subarctic Gyre:

At four of six stations ( $\mathrm{Hb2418}, \mathrm{Hb2422}, \mathrm{Oy} 3428$ and Oy2321) Thick-billed Murres ate fish. Half-digested and unidentifiable fish larvae were found in two individuals at $\mathrm{Hb3428}$ and Oy2321. At three stations, Hb2418, Hb2422 and Oy3428, lantern fish were found in their stomachs: Stenobrachius nanochir at Hb2418 and blue lanternfish (Tarletonbeania crenularis) at Hb2422. Three individuals of the latter fish were present. On the other hand one juvenile fish was found in 17 Tufted Puffins taken from this area. 
Subarctic Current:

Unidentifiable fish larvae were eaten by murres at Sts.Oy2324 and It3430. Lanternfish were eaten at Sts.Oy2324, It3515 and Oy3422. Species identification was successful at St.Oy2324: the northern lanternfish (Stenobrachius leucopsarus). The three-spine stickleback (Gasterosteus aculeatus) was eaten at Sts.Oy3504, Oy 2318 and It3515. These stations and those at which three-spine sticklebacks were found in stomachs of coho salmon (Oncorhynchus kisutsh) during 1974 (Hirakawa, unpubl. data) are plotted in Fig. 8. This shows that the three-spine stickleback, previously thought to be coastal, can indeed occur as far as $960 \mathrm{~km}$ from land. Unidentifiable fish were found in the stomachs of murres at Sts.Oy3512, Oy2324, Oy2323, Oy2318 and Oy3423.

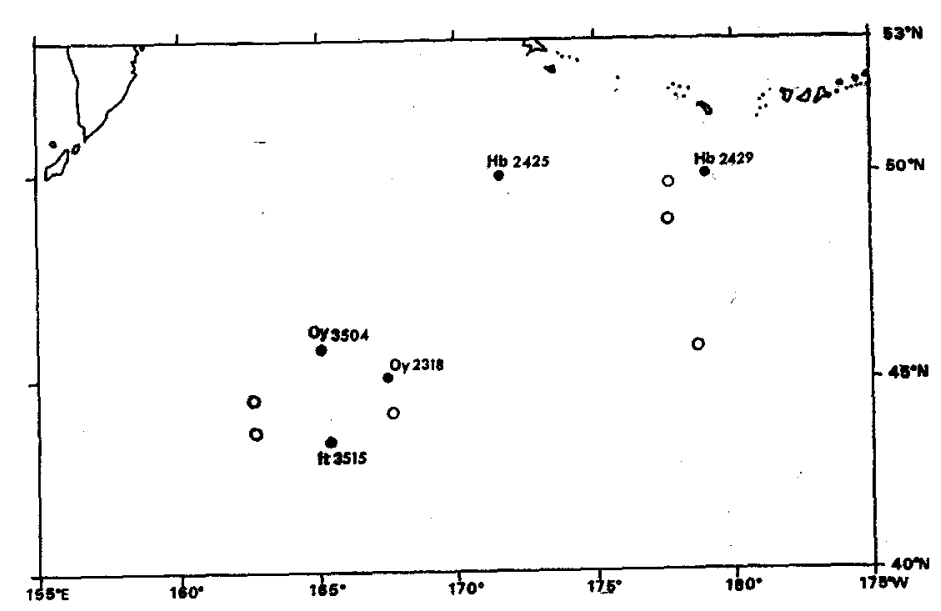

Fig. 8. Locations where the three-spine stickleback was observed in the stomach contents of Thick-billed Murres (๑) in 1972 and 1973 and ooho salmon (o) in 1974.

Thirteen of 58 Tufted Puffins fed on fish in this area. Species could be identified in only three stomachs: northern smoothtongue (Leuroglossus stilbius) and juvenile Atka mackerel were found at St.Oy3510 and Ik3511, respectively. One Tufted Puffin at St.It3508 fed on 41 juvenile Atka mackerel. The northern smoothtongue a characteristic bathypelagic fish that forms larger schools and plays a significant role in the biology of the ocean ${ }^{19}$ ). It has been recorded from the sea surface to $4000 \mathrm{~m}$ in the Pacific region ${ }^{10)-25}$ ), but biological information on it in the epipelagic layer is scarce. It was rarely caught during night by surfacemidwater trawls and drift gill nets consisting of fine mesh sizes, except in coastal areas of the Okhotsk Sea off northern Hokkaido (Table 4). However, at St.HOM-77-18 the echosounder recorded a dense shoal of northern smoothtongue within $300 \mathrm{~m}$ of the surface at dusk. Thus it could be an important component in the epipelagic community at that time.

Alaskan Stream:

A lanternfish was eaten at St.Hb2429 but I could not identify it to species. The three-spine stickleback was eaten at Sts.Hb2425 and Hb2429. Two juvenile

$$
-61-
$$


Bull. Fac. Fish. Hokkaido Univ. 31(1). 1980.

Table 4. Catch records of northern smoothtongue (Leuroglossus stilbius) in the Okhotsk Sea in 1977 and 1978.

\begin{tabular}{|c|c|c|c|c|c|c|c|c|}
\hline \multirow[b]{2}{*}{ Date } & \multirow{2}{*}{$\begin{array}{c}\text { Position } \\
\text { (Station No.) }\end{array}$} & \multirow[b]{2}{*}{ Gear } & \multicolumn{2}{|c|}{ Time } & \multirow{2}{*}{$\underset{(\mathrm{m})}{\text { Depth }}$} & \multirow{2}{*}{$\begin{array}{l}\text { No. of } \\
\text { Fish }\end{array}$} & \multirow{2}{*}{$\begin{array}{l}\text { Body } \\
\text { Length } \\
\text { (mm) }\end{array}$} & \multirow{2}{*}{$\begin{array}{l}\text { Body } \\
\text { Weight } \\
\text { (g) }\end{array}$} \\
\hline & & & $\begin{array}{l}\text { Net } \\
\text { Set }\end{array}$ & $\begin{array}{l}\text { Net } \\
\text { Haul }\end{array}$ & & & & \\
\hline 9 July 1977 & $\begin{array}{l}44^{\circ} 15^{\prime} \mathrm{N} 144^{\circ} 49^{\prime} \mathrm{E} \\
\text { (St. HO-M-77-18) }\end{array}$ & Trawl & $20: 41$ & $21: 50$ & $11-16$ & 1502 & $\begin{array}{c}\text { 53. } 9-154.2 \\
(14)^{*}\end{array}$ & $\begin{array}{c}0.868-28.022 \\
(14)^{*}\end{array}$ \\
\hline 11 July 1977 & $\begin{array}{l}44^{\circ} 24^{\prime} \mathrm{N} 145^{\circ} 10^{\prime} \mathrm{E} \\
\text { (St. HO-M-77-24) }\end{array}$ & Trawl & $19: 43$ & $21: 20$ & 一** & $c a 500$ & $\begin{array}{l}59.5 \\
(1)^{*}\end{array}$ & $\begin{array}{l}1,406 \\
(1)^{*}\end{array}$ \\
\hline 11-12 July 1977 & $\begin{array}{l}44^{\circ} 18^{\prime} \mathrm{N} 145^{\circ} 04^{\prime} \mathrm{E} \\
\text { (St. HO-G-77-06) }\end{array}$ & $\begin{array}{l}\text { Gill } \\
\text { Net }\end{array}$ & 28: 02 & $06: 06$ & $0-5$ & 8 & -**" & $-* *$ \\
\hline 25-26June 1978 & $\begin{array}{l}44^{\circ} 16^{\prime} \mathrm{N} 144^{\circ} 27^{\prime} \mathrm{E} \\
\text { (HOG (L) } 78-17)\end{array}$ & $\begin{array}{l}\text { Gill } \\
\text { Net }\end{array}$ & $18: 29$ & 05:19 & $0-5$ & 2 & $\begin{array}{c}133-146 \\
(2)^{*}\end{array}$ & $\stackrel{23}{(1)^{*}}$ \\
\hline
\end{tabular}

* number of fish measured.

** no information available.

Data source: Far Seas Fish. Res. Lab. and Fac. Fish. Hokkaido Univ. (1978)

Research report on the young salmon in the coastal waters of Hokkaido, June 24-July 14, 1977.

Far Seas Fish. Res. Lab. (1979)

Research report on the young salmon in the coastal waters of Hokkaido, June 2-July 2, 1978.

longnose lancetfish (Alepisaurus ferox) were found in one stomach at St.Hb2429. Digested fish were found at Sts.Hb2424 and Hb2501.

At St.Hb2425, 14 Tufted Puffins were sampled but no fish were observed in their stomachs.

West Wind Drift:

Lanternfish were eaten by Thick-billed Murres at four stations (It3511, Ri 3428, Ri3509 and Ri3425) but species identification was not possible. One Thickbilled Murre at St.Ri3428 had $32.9 \mathrm{~g}$ of lanternfish in its stomach. At St.Ri3509, in the stomach of one individual, 12 lanternfish were present, weighing $26.5 \mathrm{~g}$. In this area, bigfin lanternfish (Symbolophorus californiense) were often sampled by surface plankton tows during the night. This fish might be eaten by Thick-billed Murres at dawn and dusk. Unidentifiable, digested fish were found in murre stomachs at Sts.It3425 and Ri3522. Most were probably lanternfish, judging from their scales.

Northern Subtropical area:

No fish were found in the stomachs of Thick-billed Murres except at St.Hn3419. There, digested fish occurred in one sample. The mean weight of stomach contents was lower here than at any other area. The feeding schedules of murres in the northern subtropical area could be different than in other area, or feeding conditions could be less suitable for these subarctic birds.

\section{ii. Euphausiids.}

The number of euphausiids and their total weight by species in the stomach contents of each Thick-billed Murre at each sampling station are listed in Table 5. Euphausiids were abundant in the stomachs of murres in the East Kamchatka 
Oar: Pelagic feeding ecology of Thick-billed Murres

Table 5. Number, weight and species of euphausids fed on by Thick-billed Murres in the northern North Pacific Ocean, 1972 and1973.

\begin{tabular}{|c|c|c|c|c|c|}
\hline Area & Station & $\begin{array}{l}\text { Code No. } \\
\text { of Bird }\end{array}$ & $\begin{array}{c}\text { No. } \\
\text { Euphausiid }\end{array}$ & Weight $(\mathrm{g})$ & Speoies \\
\hline $\begin{array}{l}\text { East Kamchatka } \\
\text { Current }\end{array}$ & $\begin{array}{l}\text { Hb3607 } \\
\text { Hb3608 } \\
\text { Hb3609 } \\
\text { Hb3610 }\end{array}$ & $\begin{array}{l}30954 \\
30955 \\
30957 \\
30548 \\
30553 \\
31559 \\
31279 \\
31561 \\
31594 \\
30909 \\
30094\end{array}$ & $\begin{array}{r}61 \\
3 \\
2246 \\
- \\
1010 \\
480 \\
1532 \\
16 \\
2 \\
342 \\
130\end{array}$ & $\begin{array}{r}2.75 \\
0.05 \\
33.96 \\
2.04 \\
14.46 \\
8.86 \\
21.11 \\
0.33 \\
1.81 \\
7.74 \\
8.17\end{array}$ & $\begin{array}{l}- \\
\text { T. inermis } \\
\text { T. inermis } \\
\text { T. inermis } \\
- \\
\text { T. inermis } \\
\text { T. longipes (114), } \\
\text { T. inermis (16) }\end{array}$ \\
\hline $\begin{array}{l}\text { Western Subarctic } \\
\text { Gyre }\end{array}$ & $\begin{array}{l}\text { Hb2418 } \\
\text { Hb2422 }\end{array}$ & $\begin{array}{l}106 \\
259 \\
241 \\
243 \\
245\end{array}$ & $\begin{array}{l}159 \\
254 \\
- \\
-\end{array}$ & $\begin{array}{r}11.74 \\
29.95 \\
0.31 \\
0.16 \\
0.36 \\
\end{array}$ & $\begin{array}{c}\text { T. longipes } \\
\text { T. longipes } \\
\text { - } \\
-\end{array}$ \\
\hline Subarctic Current & $\begin{array}{l}\text { Oy3516 } \\
\text { Oy2320 } \\
\\
\text { Oy2323 } \\
\\
\text { Oy2318 } \\
\text { It } 3430\end{array}$ & $\begin{array}{r}641 \\
017 \\
021 \\
024 \\
037 \\
038 \\
013 \\
73018\end{array}$ & $\begin{array}{l}117 \\
- \\
- \\
= \\
-\end{array}$ & $\begin{array}{r}22.91 \\
7.43 \\
2.00 \\
19.30 \\
6.00 \\
8.37 \\
1.00 \\
0.01\end{array}$ & $\begin{array}{c}T . \text { longipes } \\
- \\
T \text { longipes } \\
- \\
- \\
-\end{array}$ \\
\hline Alaskan stream & $\begin{array}{l}\text { Hb2424 } \\
\text { Hb2425 } \\
\text { Hb2429 } \\
\text { Hb2501 }\end{array}$ & $\begin{array}{l}194 \\
264 \\
164 \\
166 \\
115 .\end{array}$ & $\frac{5}{-}$ & $\begin{array}{l}0.81 \\
7.95 \\
1.43 \\
2.12 \\
0.02\end{array}$ & $\begin{array}{l}- \\
- \\
-\end{array}$ \\
\hline
\end{tabular}

Current. Thysanoessa inermis was most frequently found. At St.Hb3610, Thysanoessa longipes was observed with $T$. inermis, but the former was much more numerous. $T$. inermis was found in bird stomachs collected near the northern Kuril Islands. In particular, this species seemed to be confined to collections from the continental slope areas. $T$. longipes was found in samples taken farther offshore. This is different from what Nemoto ${ }^{26}$ ) observed. He indicated that these two euphausiids have a similar distribution in the North Pacific Ocean based on analysis of whale stomach contents. Perhaps the whales were taken in areas away from where they had fed. Many euphausiids occurred in murre stomachs at Sts.Hb3607, Hb3608 and $\mathrm{Hb3610}$, and quite a few were found at St.Hb3609, a locality somewhat distant from the others. The greatest number found in a single murre was 2246 at St.Hb3607, in the East Kamchatka Current. Most were half-digested which necessitated the conversion of euphausiid numbers to the weight of fresh individuals in order to determine total weight. A length-weight relationship ${ }^{27}$ ) was used. The total converted weight was $180-220 \mathrm{~g}$ in a single 
stomach. In contrast to $T$. inermis, $T$. longipes was never found in large amounts in stomachs. This may be related to the vertical distribution of euphausiid swarms in the epipelagic layer which may differ according to oceanographic conditions.

Euphausiids were not eaten by the Tufted Puffins sampled in either the West Wind Drift or the northern subtropics. The percentage of Tufted Puffin stomachs containing euphausiids was $36.6 \%$ in the East Kamchatka Current, 50\% in the Okhotsk Water area, $5.9 \%$ in the Western Subarctic Gyre, $30.6 \%$ in the Subarctic Current, and 5.5\% in the Alaskan Stream. In the Western Subarctic Gyre and Alaskan Stream the percentages of Tufted Puffins eating euphausiids were smaller than for Thick-billed Murres. Overall, however, Tufted Puffins seemed to eat more euphausiids than the Thick-billed Murre. This suggests that the puffin may be more of a nueston-feeder than the murre.

\section{iii. Amphipods.}

Amphipods were prey at five stations: Hb3607, Ho3618, Hb2422, Oy2324 and It3430. These were identified to species at three stations: one individual of Hyperia galba at Hb3607, two individuals at $\mathrm{Hb2422}$ and one at It3430.

iv. Squid.

Table 6 shows species of squid in the stomachs of Thick-billed Murres. All belonged to a single family, Gonatidae.

Gonatopsis borealis has been recorded throughout the subarctic region from the northern Bering Sea to the Subarctic Boundary ${ }^{28)-34)}$. Roper and Young ${ }^{33)}$ concluded that juvenile $G$. borealis off California occurred from 400 to $700 \mathrm{~m}$ deep during the day and 200 to $1000 \mathrm{~m}$ during the night. There is thus a vertical migration of about $200-300 \mathrm{~m}$. The fact that this species was often caught by gill-nets in the northern North Pacific Ocean, Okhotsk and Bering Sea regions ${ }^{34}$, indicates that it also occurs at the surface. The range of mantle lengths of $G$. borealis caught by these nets ranged from 11 to $30 \mathrm{~cm}$, all of which were mature individuals ${ }^{35)}$. $\quad G$. borealis eaten by Thick-billed Murres were thought to be in juvenile or semi-adult stages as determined by mantle length. The murres apparently fed on this squid at dawn and dusk.

Berryteuthis magister has been recorded from the Sea of Japan; the area near the Kuril Islands and the Aleutian Islands; the continental slope of the Bering Sea and Oregon; and in Puget Sound ${ }^{31) 32) 34) 36}$. This was the squid most frequently fed on by Thick-billed Murres and other alcids in the subarctic north Pacific Ocean except in the East Kamchatka Current and Okhotsk Water areas (Table 6). Mantle lengths of all $B$. magister indicated they were juveniles. This species is also eaten by the sperm whale ${ }^{28) 37}$, the northern fur seal ${ }^{38) 39)}$, coho salmon ${ }^{40}$ ) and Albatrossia pectoralis ${ }^{41)}$. B. magister has sometimes been taken by IKMT at night in depths from 3 to $5 \mathrm{~m}$ and has been taken by herring seines and salmon traps in the surface layer ${ }^{33)}$. Roper and Young ${ }^{33)}$ considered this species to associate with the ocean bottom in a certain period of its life cycle. Larval and juvenile $B$. magister (up to 17-20 mm in mantle length) are not supposed to be present in the epipelagic layer (Kubodera pers. comm.), but older individuals are known to rise to the surface during the night. Juvenile $B$. magister must also occur in the epipelagic layer, because murres would not otherwise have eaten them.

$$
-64-
$$


Oar: Pelagic feeding ecology of Thick-billed Murres

Table 6. Species of squid found in the stomach contents of Thick-billed Murres during 1972 and 1973.

\begin{tabular}{|c|c|c|c|c|}
\hline Area & Station & $\begin{array}{l}\text { Code No. } \\
\text { of Bird }\end{array}$ & Species (Number) & $\begin{array}{c}\text { Mantle Length } \\
\text { (cm) }\end{array}$ \\
\hline Western Subarctic Gyre & Hb 2422 & 240 & Gonatopsis borealis (1) & $7-8$ \\
\hline Subarctic Current & $\begin{array}{l}\text { It } 3515 \\
\text { Ik } 3513 \\
\text { Oy2323 } \\
\text { Oy2320 } \\
\text { Oy2324 }\end{array}$ & $\begin{array}{r}73014 \\
\\
638 \\
645 \\
\\
039 \\
018 \\
044\end{array}$ & $\begin{array}{l}\text { Gonatus sp. (1) } \\
\text { Berryteuthis magister (3) } \\
\text { Unidentify (2) } \\
\text { Berryteuthis magister (1) } \\
\text { Berryteuthis anonychus (4) } \\
\text { Berryteuthis sp. (1) } \\
\text { Berryteuthis magister (2) } \\
\text { Berryteuthis magister (9) } \\
\text { Unidentify (2) } \\
\text { Gonatopsis borealis (2) } \\
\text { Unidentiy (3) }\end{array}$ & $\begin{array}{l}\overline{8-9} \\
-\overline{9-9.5} \\
8-10 \\
8-9 \\
7-8 \\
4-5 \\
- \\
6.5-7.0 \\
-\end{array}$ \\
\hline Alaskan Stream & $\begin{array}{l}\text { Hb2424 } \\
\text { Hb2501 } \\
\text { Hb2428 }\end{array}$ & $\begin{array}{l}132 \\
115 \\
141 \\
701 \\
140\end{array}$ & $\begin{array}{l}\text { Berryteuthis magister (7) } \\
\text { Unidentify (2) } \\
\text { Berryteuthis magister (6) } \\
\text { Gonatopsis borealis (1) } \\
\text { Gonatus sp. (1) } \\
\text { Gonatidae (2) }\end{array}$ & $\begin{array}{c}\frac{6-7}{-} \\
7-8 \\
9.5-10.5 \\
-\end{array}$ \\
\hline West Wind Drift & $\begin{array}{l}\text { Ik } 3510 \\
\text { Ri } 3428 \\
\text { Hi } 3522\end{array}$ & $\begin{array}{r}528 \\
530 \\
30503 \\
30517\end{array}$ & $\begin{array}{l}\text { Berryteuthis anonychus (5) } \\
\text { Gonatopsis sp. (1) } \\
\text { Berryteuthis magister (2) } \\
\text { Gonatidae (5) } \\
\text { Berryteuthis magister (1) } \\
\text { Unidentify (4) }\end{array}$ & $\begin{array}{c}8-9 \\
10-13 \\
5-6 \\
- \\
6.5-7.5 \\
-\end{array}$ \\
\hline
\end{tabular}

Most squid eaten by Tufted Puffins could not be identified to species because of their small size and the deep bill cuts on the mantle. In only one case could the squid be identified: four B. magister and five Gonatidae sp. at St.Hb2422 in the Western Subarctic Gyre.

Berryteuthis anonychus has been recorded from oceanic waters off Oregon ${ }^{30) 42)}$ and from coastal and oceanic waters off Washington and Canada ${ }^{32}$. Little else has heretofore been known about its distribution in the North Pacific. In the present study, it was recorded in Thick-billed Murre stomachs from the southern Subarctic Current (St.Ik3513) and West Wind Drift (St.Ik3510) (Table 6). Kubodera (pers. comm.) obtained specimens of $B$. anonychus (mantle length: 11-12 $\mathrm{cm}$ ) from the stomach of a longnose lancetfish caught in the Transitional Domain (ca. $45^{\circ} 00^{\prime} \mathrm{N}$, $\left.163^{\circ} 00^{\prime} \mathrm{W}\right)$. The gonads of his squid were fully developed. In contrast, the gonads of $B$. anonychus in the present study were not so well developed indicating them to be in their semi-adult stage. Larval and juvenile $B$. anonychus were often found in the stomachs of Short-tailed Shearwaters (Puffinus tenuirostris) in the southern part of the central Bering Sea (Ogi, unpubl. data). This squid, during at least the early part of its life history, thus occurs throughout the subarctic Pacific epipelagic layer.

Table 7 gives the number of squid in stomachs of Thick-billed Murres, and the 
Bull. Fac. Fish. Hokkaido Univ. 31(1). 1980.

Table 7. Murre stomachs in which squid counts were available: number of stomachs, range in

\begin{tabular}{c|c|c|c|c|c|c|c|c}
\hline Area & \multicolumn{3}{|c|}{ Western Subarctic Gyre } & \multicolumn{4}{c}{ Subarctic Current } \\
\hline Station & Hb 2418 & Hb 2422 & Oy 2321 & Oy 2320 & Oy 2324 & Oy 2323 & Oy 2318 & Ik 3513 \\
\hline $\mathrm{N}$ & 18 & 15 & 9 & 10 & 7 & 3 & 13 & 4 \\
$\operatorname{can}^{*}$ & 3 & 5 & 1 & 4 & 1 & 1 & 2 & 1 \\
$R^{* * *}$ & $1-8$ & $1-5$ & 4 & $1-13$ & 1 & 2 & $4-12$ & 8 \\
$\mathbf{n}^{* * *}$ & 3.3 & 2.6 & 4 & 4.8 & 1 & 2 & 8 & 8 \\
TT**** $^{*}$ & $4-6$ & $4-8$ & - & $4-5$ & $6.5-7$ & $7-8$ & $4-7$ & $8-10$ \\
\hline
\end{tabular}

* Number of stomachs in which squid counts were possible.

** Range in number of squid per stomachs.

Table 8. Weight and number of squid beaks per individual Thick-billed Murre.

\begin{tabular}{l|r|r|r|r|r|r|r}
\hline \multirow{2}{*}{ Area } & \multirow{2}{*}{$\mathrm{N}$} & \multicolumn{3}{|c|}{ Weight (g) } & \multicolumn{3}{c}{ Number } \\
\cline { 3 - 8 } & & $\mathrm{n}(\%)$ & Range & Mean & $\mathrm{n}$ & Range & Mean \\
\hline East Kamchatka Current & 37 & $27(73.0)$ & $0.01-0.24$ & 0.06 & 27 & $1-15$ & 45 \\
Okhotsk Water & 5 & $3(60)$ & $0.01-0.12$ & 0.08 & 3 & $4-10$ & 7.7 \\
Western Subarctic Gyre & 52 & $51(98.1)$ & $0.01-0.39$ & 0.12 & 43 & $1-26$ & 9.6 \\
Subarctic Current & 98 & $90(91.8)$ & $0.005-0.34$ & 0.08 & 47 & $1-28$ & 9.6 \\
Alaskan Stream & 68 & $\mathbf{6 7}(98.5)$ & $0.01-0.27$ & 0.09 & 67 & $2-26$ & 9.1 \\
Weat Wind Drift & 43 & $28(65.1)$ & $0.01-0.11$ & 0.02 & 26 & $1-23$ & 8.1 \\
Northern Subtropics & 17 & $8(47.1)$ & $0.01-0.02$ & 0.01 & 6 & $2-8$ & 5.3 \\
\hline
\end{tabular}

range in number and the mean number of squid per stomach at each sampling station. Since almost all were in an advanced stage of digestion, numbers may be somewhat underestimated. Squid larvae were found at Sts.Ho3618, It3430 and Ri3520 but almost all were digested and fragmented. Since larger squid beaks were sometimes found in the stomachs, it is likely that Thick-billed Murres take both young and old stages. Squid beaks were commonly found in the stomachs of many seabird species in the northern North Pacific Ocean (Ogi, unpubl. data). The percentage of stomachs holding squid beaks in each area was considerably higher than that of stomachs holding fresh squid (Tables 7 and 8). The high frequency of squid beaks leads further support to the fact that squid are important prey for pelagic Thick-billed Murres.

\section{v. Thecosomata.}

One Thecosomata was found in a Thick-billed Murre stomach at St.Oy2323. This was Limacina helicina, a species commonly found in the northern Pacific and Atlantic Oceans. They often occur in swarms and are eaten by herring, cod ${ }^{43)}$ and Pacific salmon ${ }^{44) 45}$.

Tanaka ${ }^{46)}$ showed that Limacina helicina was a typical epipelagic species and inhabited almost the same depth throughout the day and night. The species seems to a likely prey for pelagic seabirds.

Clione limacina, belonging to Gymnosomata a close relative of Thecosomata, was found in one Tufted Puffin stomach at St.Hb3608 in the East Kamchatka 
OGI: Pelagic feeding ecology of Thick-billed Murres

number of squid, the mean number of squid and the range of mantle lengths at each sampling station.

\begin{tabular}{c|c|c|c|c|c|c|c|c}
\hline \hline & \multicolumn{3}{|c|}{ Alaskan Stream } & \multicolumn{2}{c}{$\begin{array}{c}\text { West Wind Drift } \\
\text { Northern } \\
\text { Subtropical Area }\end{array}$} \\
\hline It 3515 & Hb 2424 & Hb 2425 & Hb 2428 & Hb 2501 & Ik 35l0 & Ri 3428 & Ri 3522 & Oy 3420 \\
\hline 12 & 13 & 9 & 13 & 20 & 4 & 10 & 7 & 1 \\
2 & 5 & 1 & 4 & 3 & 1 & 1 & 1 & 1 \\
$1-6$ & $1-9$ & 1 & $1-4$ & $1-6$ & 6 & 7 & 5 & 1 \\
3.5 & 2.6 & 1 & 2.3 & 2.7 & 6 & 7 & 5 & 1 \\
$8-9.5$ & $6-7$ & - & $6.5-10.5$ & $7-8$ & $8-9$ & $5-6$ & $6.5-7.5$ & - \\
\hline
\end{tabular}

*** Mean number of squid per individual bird.

**** Range in mantle lengths $(\mathrm{mm})$.

Current. The number and weight eaten was 74 individuals and $1.16 \mathrm{~g}$, respectively. The soft body tissues of this organism, and its lack of a hard shell or bone, means digestion is probably very rapid. This may mean that the species has been overlooked as seabird prey.

\section{Discussion}

The diet of Thick-billed Murres in the pelagic environment was previously not known. The present study filled this information gap for part of the year. In so doing, new information was also gathered about the biology of prey species, as reviewed below. Man's knowledge of marine organisms depends on the efficiency of his sampling techniques. Seabirds probably "sample" organisms somewhat differently and thus through study of their behavior and diet we stand to learn more about the marine environment, as this paper has demonstrated.

It was found in this study that, overall, squid were the most important prey for Thick-billed Murres in the northern North Pacific Ocean. The high frequency of squid beaks in the stomachs of many marine organisms, including fish, seals and cetaceans, indicates that this highly carnivorous animal must play an important role in marine ecosystems. Squid have a great biomass and a wide range of food preferences including crustaceans and fish. A most striking feature is their ability to feed upon organisms larger than themselves. Thick-billed Murre stomachs in the present study usually contained two or more individual squid (Tables 7 and 8), especially Berryteuthis magister and B.anonychus. Gonatopsis borealis was also found but less often.

Only limited information is available on the behavior and distribution of squid. Through the present study some points about the oceanic occurrence of certain species were clarified further. Their differing occurrence as murre prey indicate behavioral differences between $B$. magister and $G$. borealis in terms of shoaling density and occurrence near the surface. The former species was often found in murre stomachs indicating that it dwells commonly in the epipelagic layer in a certain period of its life. As juveniles it probably forms dense and patchy shoals there whereas $G$. borealis may form diffuse and sporadic ones. Another point brought forth in this study was the occurrence of $B$. anonychus in the North Pacific oceanic waters where it was previously not known.

$$
-67-
$$


Bull. Frac. Fish. Hokkaido Univ. 31(1). 1980.

Zeitsev ${ }^{47}$ sampled neuston in the East Kamchatka Current during the period from 24 June to 4 September 1962. He reported that young squid (Ommatostrephes sloani), 15-20 mm in total length, were observed in higher concentration than any other neustonic organisms. These young, carnivorous cephalopods swim at the very surface. Their absence in the stomachs of Common and Thick-billed Murres is perplexing.

Squids were also quantitatively the most important prey for tropical seabirds breeding at Christmas Island ${ }^{48)}$. Since this island is isolated and has no neritic zones, these seabirds have to depend on the pelagic environment for food. Studies such as this, and the present one, are revealing the great importance ' of squid to seabirds. It may be that the availability of squid is an important factor making the existence of birds in pelagic environments possible.

Since the fishes eaten by Thick-billed Murres had to be taken from epipelagic waters, one should expect fish prey from each of the five major categories: holoepipelagic, epheboepipelagic, brephoepipelagic, nyctoepipelagic and xenoepipelagic ${ }^{49)}$. This is the case except that the most abundant components of the subractic ichthyofauna, like Pacific salmon and walleye pollock, were not observed in the stomach contents. As a whole, though, fish did not constitute a major porition of the Thick-billed Murre diet. This suggests either (1) that the availability of fish suitable for the Thick-billed Murre is rather low in the offshore waters, (2) that the period of fish concentration in the epipelagic zone did not coincide with the murre's foraging time, or (3) that Thick-billed Murres prefer other prey over fish. The fish that murres did eat do not occur in dense shoals. For example, the longnose lancetfish (Alepisaurus ferox) is a voracious predator belonging to a high trophic level and spends a solitary life in the lower epipelagic layer. This fish moves higher in the water column where cold water rises near to the surface. Pacific saury (Cololabis saira), another holoepipelagic fish, was found in the stomach of Thickbilled Murres caught just south of the Subarctic Boundary in April 1975 (Ogi, unpubl. data).

Another kind of fish eaten by the murres were lanternfish. A characteristic feature of lanternfish is their spacial migration, either passive or activie. The genera Symbolophorus and Tarletonbeania are the typical nyctoepipelagic fishes which at night migrate to the epipelagic layer ${ }^{49)}{ }^{50}$ ). It seems that lanternfish do not occur in high concentrations in the murre's environment when the latter are feeding. The fact that they are so few lanternfish may suggest that murres do not feed at night.

The three-spine stickleback, it would seem, is xenoepipelagic ${ }^{40}$ ). Scattered individuals are passively transported in the surface water current ${ }^{51) 52}$. The three-spine stickleback is an unimportant murre prey probably because of its low abundance in epipelagic layers. Its occurrence as murre prey, though, was indeed rather surprising.

Larval and juvenile Atka mackerel, brephoepipelagic fish, commonly caught in surface plankton tows at night in the subarctic North Pacific ${ }^{53)}$, were frequently eaten by such seabirds as Tufted and Horned Puffin, Short-tailed Shearwater, Crested Auklet (Aethia oristatella), Ancient Murrelet (Synthliboramphus antiquus) and Arctic Loon (Gavia arctica; Ogi, unpubl. data). Only a few however were found in murre stomachs. This may be due to the fact that juveniles have soft body tissues which rapidly digest, meaning that they could actually be more prevalent 
in the Thick-billed Murre's diet. On the other hand, their absence as murre prey may be further evidence that pelagic Thick-billed Murres do not feed at night, or that they eat fish only when the absence of other prey forces them to do so.

In this study the northern smoothtongue (Leuroglossus stilbius) was found in one Tufted Puffin taken from the Western Subarctic Gyre. Ogi and Tsujita ${ }^{54}$ reported scales of unknown species in the stomachs of murres in the southeastern Bering Sea and Bristol Bay; subsequently these were identified as those of the northern smoothtongue. This species was common in the stomachs of Common and Thick-billed Murres from the outer continental slope between the Pribilof Islands and Unimak Pass in the southeastern Bering Sea (Ogi, unpubl. data). Other evidence suggests that Thick-billed Murres feed mostly during day light, especially at dawn and dusk. If this is so, the presence of the smoothtongue in their diet, indicates that this fish, a largely bathypelagic species, can be epipelagic during that time.

As for planktonic prey, euphausiids were the most important for Thick-billed Murres. Zeitsev ${ }^{47}$ ) demonstrated that the neuston of high latitudes has a distinct circadian rhythm in its species composition and density due to vertical migrations of abundant crustaceans such as hyperid amphipods and euphausiids. Other characteristic features of the subarctic neuston are (1) the few endemic species in the epipelagic layer, (2) the many littoral or neritic species, (3) the scarcity of species indiginous to certain water masses, (4) the large number of predatory species of higher trophic levels, and (5) the dependence of neuston distribution and density on oceanographic climate (Kamba, pers. comm.). The dense distribution of euphausiids in surface waters seems to be influenced by various biological and physical factors such as their food concentration, water temperature and salinity, and the existence of local upwelling and sea fronts. Many euphausiid swarms migrate to the very surface where they are within reach of seabirds ${ }^{55 t}$. For example, Thysanoessa longipes begin to form dense surface swarms in their post furcilia stage $^{56)}$. The population density within euphausiid swarms can be high: 60000 individuals $/ \mathrm{m}^{3}$ for $E$. superba in the Antarctic ${ }^{57)}$, and $30000 / \mathrm{m}^{3}$ for $E$. krohnii ${ }^{58)}$, and $60000000 / \mathrm{m}^{3}$ for $T$. longicaudata in the North Atlantic ${ }^{59)}$. Becaue of such high densities, euphausiids offer extremely favorable opportunities for feeding seabirds. But, since surface swarms are effected by a variety of biological and environmental factors, availability for seabirds is temporal and local. This explains why euphausiids occurred infrequently in murre stomachs, but were sometimes very numerous when they did. On the other hand, the murres may prey on euphausiids only when squid are not available.

\section{Acknowledgements}

I am grateful to a large number of people for their co-operation to take seabird samples at sea: Capt. S. Yamamoto and Mr. K. Ishii, Dr. K. Shimazaki of the Faculty of Fisheries, Hokkaido University; Dr. T. Nishiyama of the Institute of Marine Science, University of Alaska; Mr. M. Narita of the Federation of Japan Salmon Fisheries Cooperative Associations; Mr. T. Kobayashi of the Hokkaido Kushiro Fisheries Experimental Station; Mr. S. Nagahora and Mr. J. Iwakiri of the Iwate Prefectural Fisheries Experimental Station; Mr. T. Sato of the Fuku- 
Bull. Fac. Fish. Hokkaido Univ. 31(1). 1980.

shima Prefectural Fisheries Experimental Station; and Mr. S. Nakamura and Capt. I. Kotake of the Japan Marine Fishery Resources Research Center. I also grateful to Mr. T. Kubodera of Hokkaido University for help in identification of squid; Dr. K. Ohtani of Hokkaido University and Mr. M. Kamba of the Japan Atomic Power Co. for their valuable suggestions and comments. Mr. H. Hirakawa of the Fukushima Prefectural Fisheries Experimental Station provided unpublished data from his studies on Pacific salmons. Former Professor T. Tsujita and Professor S. Mishima of the Faculty of Fisheries, Hokkaido University provided many advices and encouragements during this study.

Finally I am very grateful to Dr. D.R. Ainley of the Point Reyes Bird Observatory, California, U.S.A. for his helpful discussion, and reading and criticism on the manuscript.

\section{References}

1) Dodimead, A. J., Favorite, F. and Hirano, T. (1963). Salmon of the North Pacific Ocean-Part II. Review of oceanography of the Subarctic Pacific Region. Bull. Int. North Pac. Fish. Comm., 13, 1-195.

2) Dodimead, A. J. (1961). Some features of the upper zone of the Subarctic Pacific Ocean. Ibid., 3, 11-24.

3) Favorite, F. (1967). The Alaskan Stream. Ibid., 21, 1-20.

4) Hirano, T. (1957). The oceanographic study on the subarctic region of the northwestern Pacific Ocean. Part I. Bull. Tolcai. Reg. Fish. Res. Lab., 15, 39-55.

5) Hirano, T. (1957). The oceanographic study on the subarctic region of the northwestern Pacific Ocean. Part II. Ibid., 15, 57-69.

6) Hirano, T. (1958). The oceanographic study on the subarctic region of the northwestern Pacific Ocean. Part III. Ibid., 15, 39-55.

7) Hirano, T. (1961). The oceanographic study on the subarctic region of the northwestern Pacific Ocean. Part IV. Ibid., 29, 11-39.

8) Koto, H. and Fujii, T. (1958). Structure of the waters in the Bering Sea and the Aleutian Region. Bull. Fac. Fish., Hokkaido Univ., 9, 149-170.

9) Ohtani, K. (1965). On the Alaskan Stream in summer. Ibid., 15, 260-273. (In Japanese with English abstract).

10) Ohtani, K. (1966). The Alaskan Stream and sockeye salmon fishing ground. Ibid., 16, 209-240. (In Japanese with English abstract).

11) Ohtani, K. (1970). Relative transport in the Alaskan Stream in winter. Jour. Oceanogr. Soc. Japan, 26, 271-282.

12) Uda, M. (1935). On the distribution, formation and movement of the dichothermal water in the northeastern sea region adjacent to Japan. Umi to Sora, 15, 445-452. (In Japanese). 13) Uda, M. (1963). Oceanography of the Subarctic Pacific Ocean. J. Fish. Res. Bd.
Canada, 20, 119-179.

14) Kikuchi, T. and Tsujita, T. (1977). Some relations between spacing of pelagic fishes in economic importance and the oceanographic structure in the northwestern North Pacific Ocean. Res. Inst. N. Pac. Fish., Hokkaido Univ., Spe. Vol., 397-438. (In Japanese with English abstract).

15) Ogi, H. and Tsujita, T. (1977). Food and feeding habits of common murre and thick-billed murre in the Okhotsk Sea in summer, 1972 and 1973 . Ibid., 459-517.

16) Melville, D. (1973). Birds and salmon nets. Seabird Report, 3, 47-50.

17) Hynes, H. B. N. (1950). The food of fresh-water sticklebacks (Gasterosteus aculeatus and Pygosteus pungitius), with a review of methods used in studies of the food of fishes. J. Anim. Ecol., 19, 36-58. 
18) Whittaker, R. H. (1952). A study of summer foliage insect communities in the Great Smoky Mountains. Ecol. Monograph., 22, 1-44.

19) Borodulina, O.D. (1968). Taxonomy and distribution of the Genus Leuroglossus (Bathylagidae, Pisces). Jour. Ichthyol., 8, 1-10.

20) Gilbert, C. H. (1895). The ichthyological collections of the steamer "Albatross" during the years 1890 and 1891. Rep. U.S. Comm. Fish., 19, 393-476.

21) Jordan, D. S. and Evermann, B. W. (1896). The fishes of North and Middle America. Bull. U.S. Nat. Mus., 47, 1-1240.

22) Shmidt, P. Yu. (1950). Fishes of the Sea of Olkhotsk. (Translated from the Russian by Ushakov, P.V., 1965). 392p. Israel Program for Scientific Translation Ltd., Jerusalem.

23) Alverson, D. L. (1951). New records for marine fishes from southeastern Alaska. Copeia, 1951, 86-87.

24) Fitch, J. E. (1951). Studies and notes on some California marine fishes. Calif. Fish and Game, 37, 111-120.

25) Barraclough, W. E. and Butler, T. H. (1961). Additional records of the argentinid fish, Leuroglossus stilbius, from British Columbia, with remarks on its taxonomy. J.-Fish. Res. Board Can., 18, 1167-1169.

26) Nemoto, T. (1962). Distribution of five main euphausiids in the Bering and the northern part of the North Pacific. J. Oceanogr. Soc. Jap., 20gh Anniversary Vol., 615-627. (In Japanese with English abstract).

27) Ponomareva, L. A. (1963). The euphausiids of the North Pacific, their distribution and ecology. (Translated from the Russian by Nemchonok, S. 1966), 154p. Israel Program for Scientific Translation Ltd., Jerusalem.

28) Okutani, T. and Nemoto, T. (1964). Squids as the food of sperm whales in the Bering Sea and Alaskan Gulf. Scient. Rep. Whales res. Inst. Tokyo, 18, 111-122.

29) Rice, D. A. (1963). Progress report on biological studies of the large Cetacea in the waters off California. Norsk Hvalfangsttid, 52, $181-187$.

30) Pearcy, W. G. (1965). Species composition and distribution of pelagic cephalopods from the Pacific Ocean off Oregon. Pacific Science, 19, 261-266.

31) Clarke, M. R. (1966). A review of the systematics and ecology of ocean squid. p. 91300. In Russel, F.S. (ed.), Advances in marine biology. (Vol. 4), 311p. Academic Press, London and New York.

32) Nesis, K. N. (1973). Taxonomy, phylogeny and evolution of squids of the family Gonatidae (Cephalopoda). Zool. Zh., 52, 1626-1638.

33) Roper, C. F. E. and Young, R. E. (1975). Vertical distribution of pelagic cephalopods. Smithsonian Contr. Zool., 209, 1-51.

34) Naito, M., Murakami, K., Kobayashi, T.; Nakayama, N. and Ogasawara, J. (1977). Distribution and migration of oceanic squids (Ommastrephes bartrami, Onychoteuthis borealijaponicus, Berryteuthis magister and Gonatopsis borealis) in the western Subarctic Pacific Region. Res. Inst. N. Pac. Fish., Hokkaido Univ., Spe. Vol., 321337. (In Japanese with English abstract).

35) Naito, M., Murakami, K. and Kobayashi, T. (1977). Growth and food habit of oceanic squids (Ommastrephes bartrami, Onychoteuthis borealijaponicus, Berryteuthis magister and Gonatopsis borealis) in the western Subarctic Pacific Region. Ibid., 339-351. (In Japanese with English abstract).

36) Okutani, T. (1968). Review of Gonatidae (Cephalopods) from the North Pacific. "Venus", the Japanese Journal of Malacology, 27, 31-34. (In Japanese).

37) Akimushkin, I. I. (1955). Cephalopods of the seas of the U.S.S.R. (Translated from the Russian by Mercado, A., 1965), 223p., Israel Program for Scientific Translation Ltd., Jerusalem.

38) Penina, G. K. (1964). Food habits of fur seals in the Sea of Japan. Trudy VNIRO, 51, 67-73. (In Russian with English abstract).

39) Fiscus, C. H., Barnes, G. A. and Kajimura, H. (1965). Pelagic fur seal investiga- 
Bull. Fac. Fish. Hokkaido Univ. 31(1). 1980.

tions, Alaska 1963. U.S. Fish Wildl. Serv. Spe. Sci. Rep. Fish., 489, 1-33.

40) Sato, T. and Hirakawa, H. (1976). The ecology of coho salmons in the northwestern North Pacific Ocean. - I. Distribution and feeding habit. Holouyo Kenkyu Kyogikai Kenkyu Hokoku, 5, 47-58. (In Japanese).

41) Sasaki, M. (1920). Report on cephalopods collected during 1906 by the United States Bureau of Fisheries steamer "Albatros" in the northwestern Pacific. Proc. U.S. Natr. Mus., 57, 163-203.

42) Pearcy, W. G. and Voss, G. L. (1963). A new species of Gonatid squid from the North-eastern Pacific. Proc. Biol. Soc. Washington, 76, 105-112.

43) Wimpenny, R.S. (1966). The plankton of the sea. 426p. Faber and Fabar Ltd., London.

44) Ito, J. (1964). Food and foeding habit of Pacific salmon (Genus Oncòrhynchus) in their oceanic life. Bull. Hokkaido Reg. Fish. Res. Lab., 29, 85-96.

45) Nishiyama, T. (1974). Energy requirement of Bristol Bay sockeye salmon in the central Bering Sea and Bristol Bay. p. 321-343. In Hood, D. W. and Kelley, E. J. (eds.), Oceanography of the Bering Sea with emphasis on renewable resoruces. 623p. Inst. Mar. Sci. Occas. Publ., 2, Univ. Alaska, Fairbanks.

46) Tanaka, T. (1969). Pteropoda and Heteropoda from the western part of the north and south Pacific Oceans. MS Thesis, Fac. Fish., Hokkaido Univ.

47) Zeitsev, Yu. P. (1970). Marine neustonolagy. (Translated from the Russian by Mercado, A., 1971), 207p. Israel Program for Scientific Translation Ltd., Jerusalem.

48) Ashmole, N. P. and Ashmole, M. J. (1967). Comparative feeding ecology of sea birds of a tropical oceanic island. Peabody Mus. Nat. Hist. Yale Univ. Bull., 24, 1-131.

49) Parin, N. V. (1968). Ichthyofauna of the epipelagic zome. (Translated from the Russian by Raveh, M., 1970), 205p. Israel Program for Scientific Translation Ltd., Jerusalem.

50) Pearey, W. G. (1964). Some distributional features of mesopelagic fishes off Oregon. J. mar. Res., 22, 83-102.

51) Harden Jones, F. R. (1968). Fish migration. 325p. St. Martin's Press, New York.

52) Williams, F. (1972). Consideration of three proposed models of the migration of young skipjack tuna (Katsuonus pelamis) into the eastern Pacific Ocean. Fish. Bull., 70, 741-762.

53) Gorbunova, N. N. (1962). Spawning and development of greenlings (Family Hexagrammidae). p. 121-185. In Rass, T. S. (ed.), Greenlings, taxonomy, biology, interoceanic transplantation. (Translated from the Russian by Raveh, M., 1970), 207p. Israel Program for Soientific Translation Ltd., Jerusalem.

54) Ogi, H. and Trujita, T. (1973). Preliminary examination of stomach contents of murres (Uria spp.) from the eastern Bering Sea and Bristol Bay, June- August, 1970 and 1971. Jap. J. Ecol., 23, 201-209.

55) Boden, B. P., Johnson, M. W. and Brinton, E. (1955). The Euphausiacea (Crustacea) of the North Pacific. Bull. Scripps Inst. Oceanogr., Univ. California, 6, 287-400.

56) Nemoto, T. (1974). Euphausiids. p. 129-149. In Marumo, R. (ed.), Marine plankton. 232p. (Vol. 10), Todai Shuppan Kai, Tokyo. (In Japanese).

57) Marr, J. W. S. (1962). The natural history and geography of the Antarctic krill (Euphausia superba Dana). Discovery Rept., 32, 33-464.

58) Baker, A. de C. (1970). The vertical distribution of euphausiids near Fuerteventura, Canary Islands (Discovery SOND cruise, 1965). J. Mar. Biol. Assoc. U.K., 50, 301-342.

59) Forsyth, D. C. T. and Jones, L. T. (1966). Swarming of Thysanoessa longicaudata (Kroyer) (Crustacea, Euphausiacea) in the Shetland Island. Nature, 212, 1467-1468. 